\title{
EXPERIMENTAL STUDY ON RADIOACTIVE WASTE IMMOBILIZATION IN LOW-TEMPERATURE MAGNESIUM- POTASSIUM PHOSPHATE CERAMIC MATRIX
}

\author{
S.Yu. Sayenko, V.A. Shkuropatenko, A.V. Pylypenko, A.V. Zykova, \\ S.A. Karsim, V.V. Andrieieva, S.V. Moshta \\ National Science Center "Kharkov Institute of Physics and Technology", Kharkiv, Ukraine \\ E-mail: shkuropatenko@kipt.kharkov.ua; tel./fax +38(057)335-39-05
}

Results of the studies carried out in NSC KIPT on application of magnesium-potassium phosphate ceramic matrices for immobilization of cesium, clinoptilolite with a cesium and solidified simulators of highly-active waste with high salt content are presented. The high radiation stability and corrosion resistance of the magnesiumpotassium phosphate ceramic matrices to leaching of radionuclide simulators, as well as basic components of solidified ceramic compounds were determined. It was shown that magnesium-potassium phosphate matrices for the solidification of liquid radioactive wastes of low and middle activity level, including waste with increased salt content, can be used in Ukrainian NPPs.

\section{INTRODUCTION}

Activities of nuclear fuel cycle industry, nuclear power plants (NPPs), production and application of radioisotope products, etc. resulted in the accumulation of a large amount of radioactive waste. The main purpose of radioactive waste management is to prevent the harmful effects on humans and the environment during the whole period of potential activity of the hazardous waste. The process of the radioactive waste immobilization into a chemically stable form, which retains the stability during the period required to reduce radioactivity to the level of the natural background $[1,2]$, is an effective way to realize such strategy.

Traditional methods of radioactive waste isolation are vitrification, cementation, and application of thermosolid polymers or mineral matrices. Each of the methods has some advantages and disadvantages. Thus, along with acceptable physical and mechanical properties such as mechanical strength, thermophysical characteristics and radiation resistance, glass matrix materials demonstrate a number of disadvantages (thermodynamic instability, spontaneous crystallization), which are devoid of crystalline matrix materials. However, both crystalline and glass matrices producing requires high temperatures treatment process. The long-term high-temperature waste treatment is an energy-intensive and expensive process when implemented in large scale. Therefore, there is a need for low-temperature technology in the field of radioactive waste processing.

One of the existing low-temperature approaches for radioactive waste stabilization is the use of inorganic binders, such as clay materials, cement, etc. The main disadvantages of the cementing process are the low strength of cement matrices, low filling of salts, low speed of solidification, incomplete solidification of the liquid phase at high water-cement ratio [3]. The presence of a significant concentration of salts in liquid radioactive waste (LRW) has a negative effect on the course of the cement hydration reaction, which can resulted in the destruction of waste forms over time. Reducing the salt content of the cement matrix allows to avoid this restriction. However, such reducing, in turn, can lead to an increase in the volume of final forms of waste.

Alternatively, chemical bonded phosphate ceramics (CBPCs) are proposed. CBPCs were formed as a result of an acid-base reaction between acidic phosphate (such as potassium, ammonium or aluminum) and metal oxide (eg, magnesium, calcium or zinc). The reactions of various inorganic oxides with a solution of phosphoric acid were previously investigated. At the study W. Kingery [4] the cure time and increase of the mixture temperature as a result of the reactions were determined. This study showed that the products of the reactions are a set of hydrophosphates. Since then, this approach, based on acid-base reactions, has been used to synthesize a number of chemically bound phosphate materials. Zinc phosphates were used as dental cements during the first half of the twentieth century. Subsequently, a struvite (ammonium magnesium phosphate cement) and calcium aluminate were developed at Brookhaven National Laboratory (USA) on the basis of CBPCs [5]. The applications of phosphate materials for further immobilization of the radioactive and hazardous waste were proposed by researchers of the Argonne National Laboratory (ANL, USA). In particular, ANL scientists have developed magnesium-potassium phosphate ceramics $\mathrm{KMgPO}_{4} \cdot 6 \mathrm{H}_{2} \mathrm{O}$ (MPP) by reacting $\mathrm{MgO}$ with a $\mathrm{KH}_{2} \mathrm{PO}_{4}$ solution that can be used to immobilize solid, LRW and sludge. In addition, among many other studies, the possibility of isolating low-activity mixed wastes and wastes containing technetium has been explored $[6,7]$.

Magnesium-potassium phosphate $\mathrm{KMgPO}_{4} \cdot 6 \mathrm{H}_{2} \mathrm{O}$ is related to CBPCs materials and possesses a unique properties. MPP is classified as ceramic cement, which has characteristic properties of both ceramic and hydraulic materials. The microstructure of MPP is similar to the ceramics, with a strongly expressed crystalline structure. However, in the contrast to ceramics, MPP is formed at room temperature and uses water at the beginning of chemical reactions with subsequent solidification of a material similar to the manufacture of hydraulic cement compounds [8]. The 
main characteristics CBPCs materials, Portland cement and traditional ceramics are compared in Table 1. CBPCs are characterized by a strong crystalline structure and, as a rule, have better mechanical properties compared to Portland cement. Unlike Portland cement with $\mathrm{pH}$ value about 12 , the final $\mathrm{pH}$ of CBPCs is neutral, which makes it inert to the additives used to produce the various composites.

Table 1

The main characteristics of CBPCs materials, Portland cement and traditional ceramics

\begin{tabular}{|c|c|c|c|}
\hline Properties & CBPCs & Portland cement & $\begin{array}{c}\text { Traditional } \\
\text { ceramics }\end{array}$ \\
\hline $\begin{array}{c}\text { Manufacturing } \\
\text { process }\end{array}$ & $\begin{array}{c}\text { Acid-base reaction, } \\
\text { hydration, } \\
\text { solidification }\end{array}$ & $\begin{array}{c}\text { Hydration, } \\
\text { solidification }\end{array}$ & Sintering \\
\hline $\begin{array}{c}\text { Temperature of } \\
\text { solidification }\end{array}$ & Room temperature & Room temperature & High temperature \\
\hline $\begin{array}{c}\text { Acidity and } \\
\text { alkalinity of final } \\
\text { product }\end{array}$ & Neutral & Strongly alkaline & Neutral \\
\hline Crystallinity & High & Low & High \\
\hline
\end{tabular}

CBPCs are used as a material for building panels, dental material, for the quick repair of damaged roads, bridges and runways. Furthermore, the possibility of material applications for protection against neutron, $\gamma$-radiation and the safe isolation of radioactive waste is now under consideration.

At present, there is an urgent problem for the Ukrainian NPPs with the conditioning of LRW to a condition acceptable for disposal. It is known that the annual generation of LRW per unit of installed capacity ranges from $70 \mathrm{~m}^{3} / \mathrm{GW}$ (Khmelnitsky NPP) to $320 \mathrm{~m}^{3} / \mathrm{GW}$ (Rivne NPP). Such values are significantly higher than the corresponding values for WWER reactors operating in Bulgaria, Slovakia and the Czech Republic. Capacities for the bottom residue are filled by $70 . .80 \%$ (Zaporizhska and South-Ukrainian NPPs), and the resource for the placement of salt melt is close to exhaustion (Zaporizhska and Rivne NPPs) [9].

To solve the problem of LRW solidification, the magnesium-potassium phosphate ceramics application is proposed. MPP ceramics have room temperature of synthesis and demonstrate better corrosion and radiation properties than the cement compounds. The technology of MPP ceramics manufacturing is cost-effective due to the fact that the process does not require heat treatment. In addition, the solidification of magnesium-potassium phosphate occurs in a short time. The short solidification time is of special interest because of the minimization the impact of radiation on workers in the processing of radioactive waste. The starting materials for the manufacture of MPP matrices are readily available at relatively low cost. The MPP manufacturing technology is very similar to the cementing technology, which means that the same equipment can be used for the LRW cementing process [10].

\section{PRODUCTION AND RESEARCH OF MAGNESIUM-POTASSIUM PHOSPHATES WITH CESIUM}

As well known, the activity of the NPP LRW is determined by the radionuclides ${ }^{134,137} \mathrm{Cs}$ and ${ }^{60} \mathrm{Co}$ [11]. Cs is mainly present in the LRW as chloride, nitrate and sulfate and therefore well soluble in water. In addition, cesium compounds are highly volatile. Thus, many materials that require high temperatures during manufacturing process are unsuitable for use. Therefore, the study of the possibility of immobilization of cesium in a chemically stable matrix, based on magnesiumpotassium phosphate, is quite relevant.

The following reagents were used for the synthesis of magnesium-potassium phosphate:

- magnesium oxide $\mathrm{MgO}$;

- potassium dihydrophosphate $\mathrm{KH}_{2} \mathrm{PO}_{4}$;

- distilled water $(\mathrm{pH}=5.5)$.

Magnesium-potassium phosphates were produced at room temperature as a result of the acid-base reaction between magnesium oxide $\mathrm{MgO}$ and potassium dihydrophosphate $\mathrm{KH}_{2} \mathrm{PO}_{4}$ in water:

$\mathrm{MgO}+\mathrm{KH}_{2} \mathrm{PO}_{4}+5 \mathrm{H}_{2} \mathrm{O}=\mathrm{KMgPO}_{4} \cdot 6 \mathrm{H}_{2} \mathrm{O}$.

In the case of synthesis of cesium-containing MPP samples, cesium chloride $\mathrm{CsCl}$ was used as the starting reagent.

To slow down the rate of reaction of magnesium oxide with potassium dihydrophosphate, heat treatment of magnesium oxide powder was carried out at $1300{ }^{\circ} \mathrm{C}$ for $1 \mathrm{~h}$ in air. The magnesium oxide produced after heat treatment is characterized by the structure of periclase.

The dry mixture of $\mathrm{MgO}$ and $\mathrm{KH}_{2} \mathrm{PO}_{4}$ was thoroughly mixed, and then the required amount of water was added to the mixture. The resulting mass was then stirred for $20 \ldots 30 \mathrm{~min}$ until pasty. The paste was placed in a plastic form. The paste temperature was raised up to $45^{\circ} \mathrm{C}$ during $10 \mathrm{~min}$. To increase the reaction time, $1 \ldots 2 \mathrm{wt} . \%$ boric acid $\left(\mathrm{H}_{3} \mathrm{BO}_{3}\right)$ was added to the mixture. After removal from the plastic form, the MPP samples were kept at $20^{\circ} \mathrm{C}$ for 28 days. As a result, samples of compositions $\left(\mathrm{KMgPO}_{4} \cdot 6 \mathrm{H}_{2} \mathrm{O}\right)$ and $\left(\mathrm{KMgPO}_{4} \cdot 6 \mathrm{H}_{2} \mathrm{O}+(10 \ldots 15)\right.$ wt. $\left.\% \mathrm{CsCl}\right)$ were obtained in the form of a cube with dimensions $20 \times 20 \times 20 \mathrm{~mm}$ and cylindrical samples with a diameter of $19 \mathrm{~mm}$ and a height of $35 \mathrm{~mm}$ (Fig. 1,a). Using X-ray phase analysis (DRON-4-07, $\mathrm{Cu} \mathrm{K \alpha}$ ) of the obtained MPP samples, it was found that the X-ray lines correspond to the crystalline hexahydrate of double magnesium and potassium orthophosphate $\mathrm{KMgPO}_{4} \cdot 6 \mathrm{H}_{2} \mathrm{O}$ (JCPDS 350812) (see Fig. 1,b). The density of the obtained MPP samples was about $1.7 \ldots 1.8 \mathrm{~g} / \mathrm{cm}^{3}[12,13]$. 


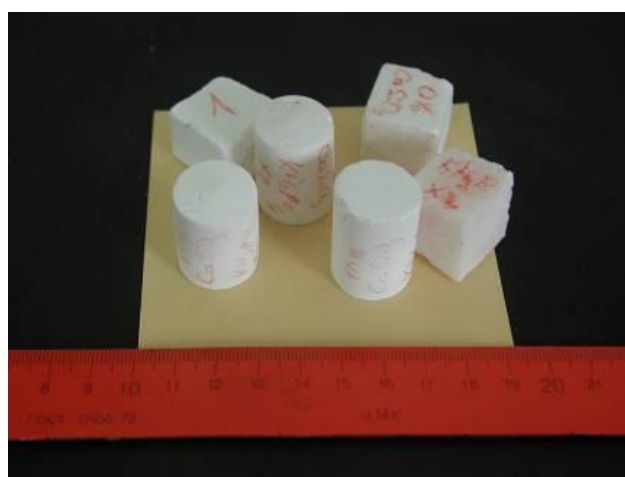

$a$

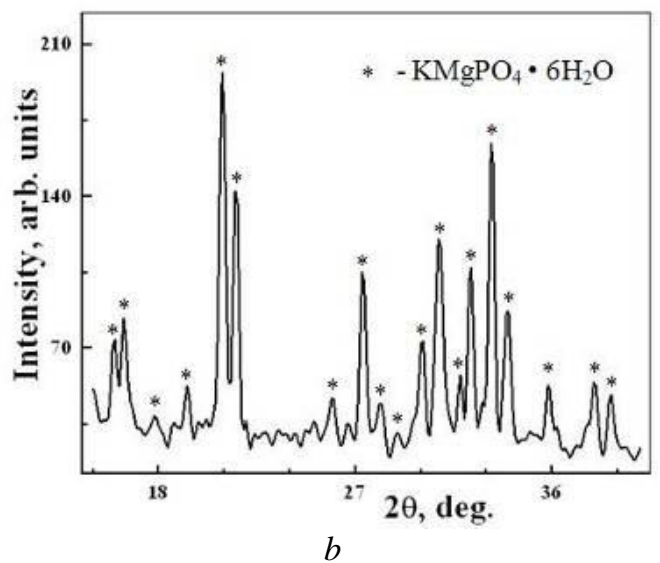

Fig. 1. MPP samples: $a-v i e w, b-X R D$ pattern

The MPP samples behavior during the heating process was determined by differential thermal and thermogravimetric analysis (DTA/TG) (Fig. 2,a). DTA/TG analysis was performed on a Simultaneous DSC-TGA SDT Q600 thermal analyzer. It was found that the endothermic peak at a temperature of $120{ }^{\circ} \mathrm{C}$ corresponds to the dehydration of magnesium potassium phosphate according to the following reaction [14]:

$$
\mathrm{KMgPO}_{4} \cdot 6 \mathrm{H}_{2} \mathrm{O} \rightarrow \mathrm{KMgPO}_{4}+6 \mathrm{H}_{2} \mathrm{O} .
$$

This fact was confirmed by weight loss $(\sim 40 \%)$ on the TG curve, which corresponds to the loss of stoichiometric amount of bound water. The small exothermic peak near the temperature of $400^{\circ} \mathrm{C}$, apparently, corresponds to the reversed phase transition $\alpha-\mathrm{KMgPO}_{4} \rightarrow \beta-\mathrm{KMgPO}_{4}$ previously found by the authors [15] during the thermal treatment of $\mathrm{K}$-struvite single crystals $\mathrm{MgKPO}_{4} \cdot 6 \mathrm{H}_{2} \mathrm{O}$ at a temperature of $362{ }^{\circ} \mathrm{C}$. After heat treatment of MPP samples at $1300{ }^{\circ} \mathrm{C}$ for $45 \mathrm{~min}$, lines of dehydrogenated potassiummagnesium monophospate phase $\alpha-\mathrm{KMgPO}_{4}$ were observed (see Fig. 2,b). These data are in good agreement with previously reported results of the X-ray phase analysis of synthesized anhydrous phosphate $\mathrm{KMgPO}_{4}$ with the addition of $\mathrm{Eu}[16]$.

As it can be seen from the above-mentioned XRD phase analysis, the obtained material in the case of MPP samples with cesium is identified as magnesiumpotassium orthophosphate, which can be generally represented as $\mathrm{K}_{1-\mathrm{x}} \mathrm{Cs}_{\mathrm{x}} \mathrm{MgPO}_{4} \cdot 6 \mathrm{H}_{2} \mathrm{O}$ (Fig. 3,a).

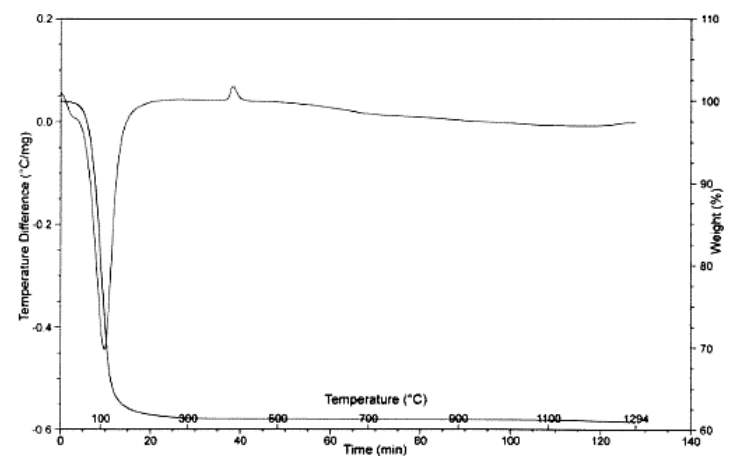

$a$

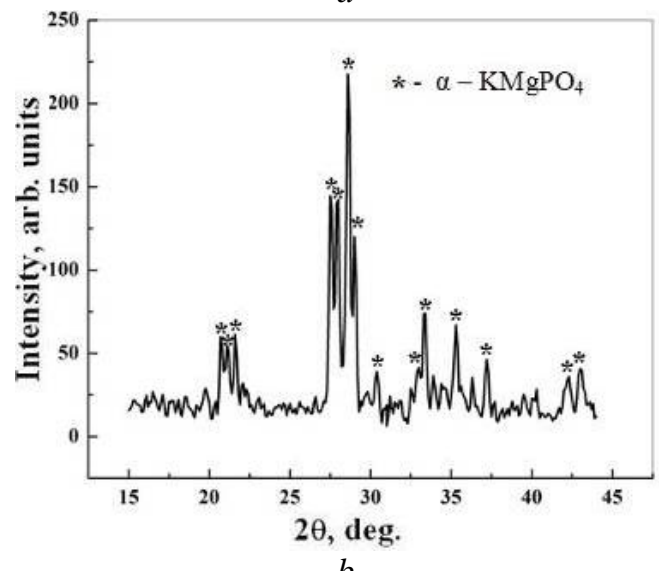

$b$

Fig. 2. MPP samples: $a-D T A / T G$ analysis, $b-X R D$ pattern after heat treatment at $1300{ }^{\circ} \mathrm{C}$ for $45 \mathrm{~min}$

In addition, the lines of chlorine-magnesium phosphate $\mathrm{Mg}_{2} \mathrm{PO}_{4} \mathrm{Cl}$ were observed on the diffraction patterns. A slight shift of the main X-ray lines $\mathrm{KMgPO}_{4} \cdot 6 \mathrm{H}_{2} \mathrm{O}$ towards smaller angles was detected comparing to the diffraction patterns of MPP and MPP +10 wt.\% CsCl (see Fig. 3,b). This fact is typical for the structural substitution of atoms by other atoms with larger ionic radii. At present study, potassium atoms were replaced by cesium atoms and lattice parameters were correspondingly increased [12].

Analysis of infrared (IR) absorption spectrum (IR spectrophotometer IRS-29 (LOMO)) of the MPP sample shows that the main bands in the IR spectrum correspond to the magnesium-potassium phosphate $\mathrm{KMgPO}_{4} \cdot 6 \mathrm{H}_{2} \mathrm{O}: 570,630,760$, and $1050 \mathrm{~cm}^{-1}$ [17] (Fig. 4,a). This fact is in a good agreement with the XRD data (see Fig. 1,b). According to the view of the IR spectrum of the MPP +10 wt.\% $\mathrm{CsCl}$ sample, the phase composition is similar to the MPP sample without $\mathrm{CsCl}$ addition, since all the bands in the spectrum coincide (see Fig. 4,a,b). The difference is that the intensity of all bands corresponding to the phosphate phases has significantly increased, and the highs have become narrower and clearer. Such changes in the spectrum are associated with a higher degree of crystallinity of the sample. In addition, the increase in crystallinity is evidenced by the XRD phase analysis of the MPP samples with and without $\mathrm{CsCl}$ addition (see Figs. 1,b, 3,a).

The general view of the IR spectrum of the sample $\mathrm{MPP}+15$ wt.\% $\mathrm{CsCl}$ similar to the spectrum of the sample with the addition of $10 \mathrm{wt} \% \mathrm{CsCl}$ (see Fig. 4,c). 


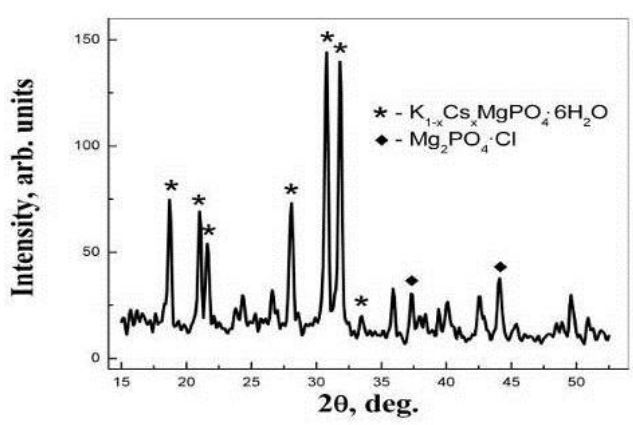

$a$

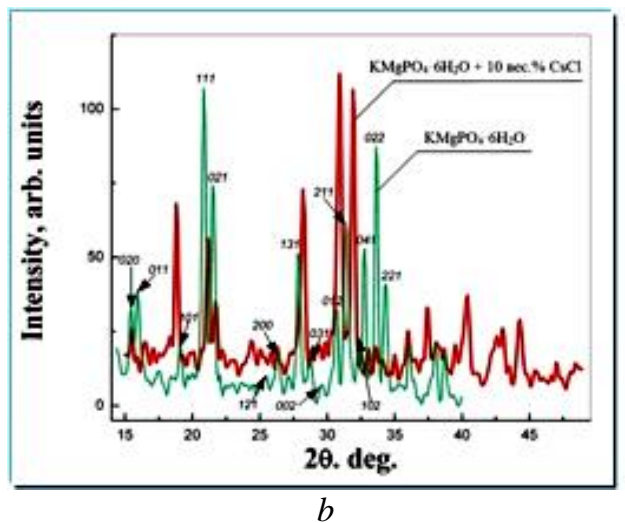

Fig. 3. XRD patterns: $a-M P P+10 w t . \% C s C l$, $b-M P P$ and MPP $+10 w t . \% \mathrm{CsCl}$ [12]

However, the difference was that the main bands corresponding to the $\mathrm{KMgPO}_{4} \cdot 6 \mathrm{H}_{2} \mathrm{O}$ phase $(565,620$, 760 , and $1040 \mathrm{~cm}^{-1}$ ) shift to the low-frequency region of the spectrum by $5 \ldots 10 \mathrm{~cm}^{-1}$, and the intensity of bands is slightly reduced. Such shifting of the absorption bands into the low-frequency region can be caused by an increase in the mass of the atoms when part of the $\mathrm{K}$ atoms was isomorphically substituted by Cs [18].

To determine the behavior of cesium containing magnesium-potassium phosphates during heating process, a heat treatment of MPP $+10 \mathrm{wt} \% \mathrm{CsCl}$ and MPP + 15 wt. \% $\mathrm{CsCl}$ samples was carried out in air at 700,1050 , and $1176^{\circ} \mathrm{C}$ with different holding times: 1 , 2.5 , and $3 \mathrm{~h}$, respectively. The experiments have shown that the heat treatment at $700{ }^{\circ} \mathrm{C}$ results in a weight loss of $27 \ldots 28 \%$. Further increasing of the temperature up to $1150{ }^{\circ} \mathrm{C}$ leads to the weight loss of the samples about $1 \%$. The sample material melts near this temperature. Elemental analysis of MPP samples with the addition of 10 wt.\% $\mathrm{CsCl}$ was performed on an EMAL-2 laser mass spectrometer. The results of elemental analysis of MPP +10 wt. $\%$ are presented in Table 2 . From the above data it can be concluded that the amount of cesium in MPP sample does not practically change with increasing processing temperature. It should be noted that the content of cesium in the MPP sample also remains the same after heat treatment at $1176{ }^{\circ} \mathrm{C}$ and a holding time of $3 \mathrm{~h}$, i.e. at the sample melting conditions.

It has been shown that Cs can be incorporated into the crystalline structure of struvite-K using acid-alkali reaction of the MPP synthesis at room temperature. Addition of cesium chloride during the reaction leads to changes in the size of the unit cell of the obtained phosphates. This fact confirms the partial replacement of potassium by cesium. Thus, the obtained MPP matrix retains the rhombohedral crystalline structure and demonstrates high heat-resistance. Moreover, even heated to high temperatures Cs remains incorporated to the MPP matrix and does not enter to environment.
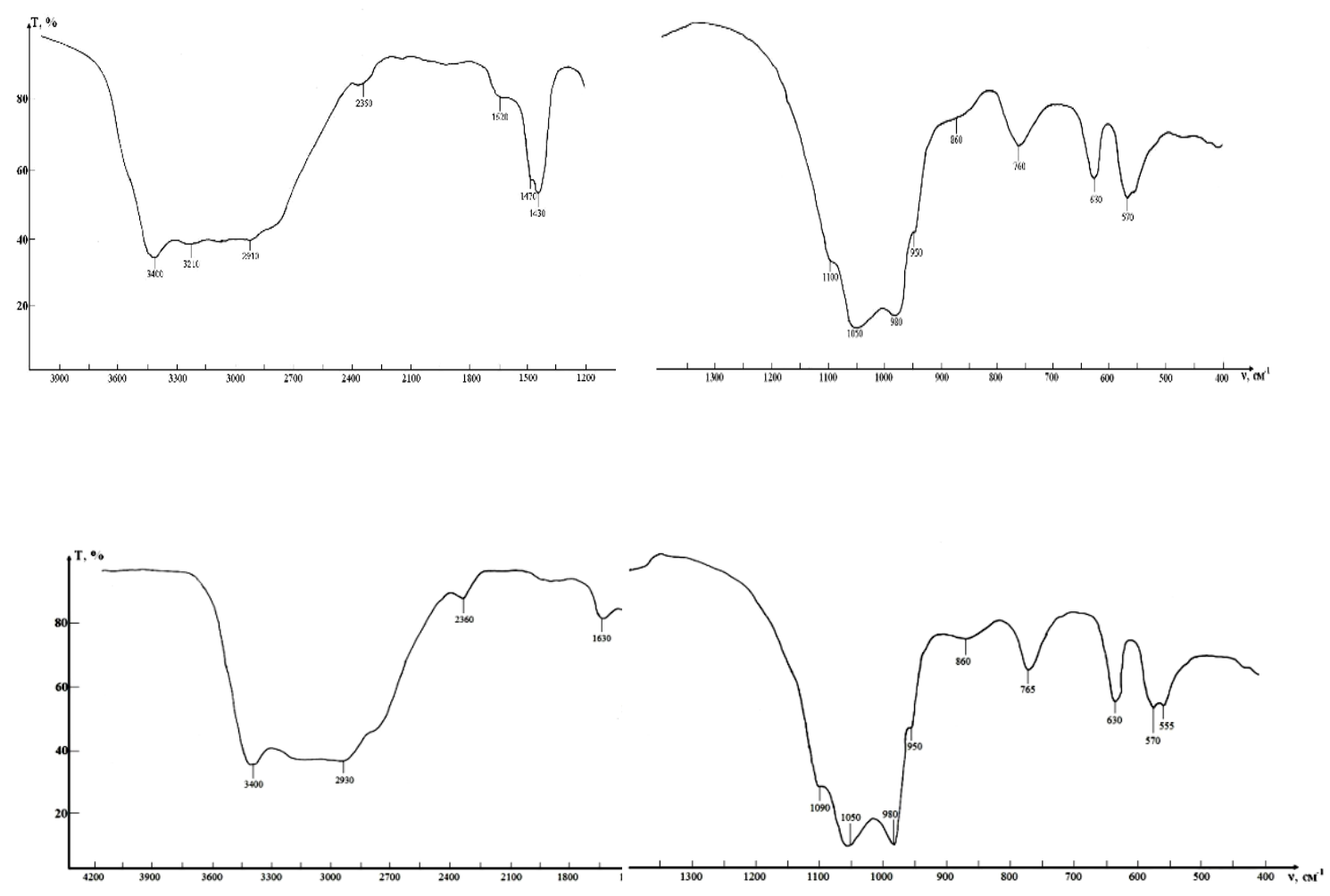

Fig. 4. IR absorption spectra of the samples: $a-M P P ; b-M P P+10 w t . \% C s C l$ 

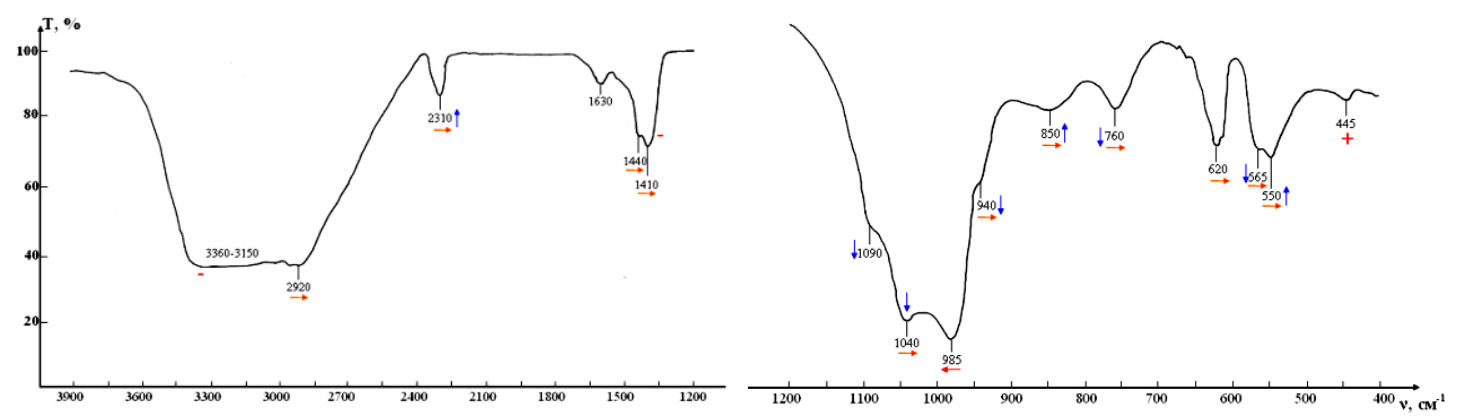

Fig. 4. IR absorption spectra of the samples: $c-M P P+15 w t . \% \mathrm{CsCl}$

Table 2

Elemental composition of MPP+10 wt.\% CsCl sample after heat treatment

\begin{tabular}{|c|c|c|c|c|c|c|c|c|c|}
\hline \multirow{2}{*}{$\begin{array}{c}\text { Temperature } \\
\text { and holding } \\
\text { time }\end{array}$} & \multicolumn{7}{|c|}{ Elemental composition, wt.\% } \\
\cline { 2 - 10 } & $\mathrm{K}$ & $\mathrm{Mg}$ & $\mathrm{P}$ & $\mathrm{O}$ & $\mathrm{Cs}$ & $\mathrm{Cl}$ & $\mathrm{Na}$ & $\mathrm{Si}$ & $\mathrm{S}$ \\
\hline $700^{\circ} \mathrm{C}, 1 \mathrm{~h}$ & 9.9 & 24.1 & 14.6 & 30.8 & 10.3 & 5.9 & 3.5 & 0.2 & 0.7 \\
\hline $1050^{\circ} \mathrm{C}, 2.5 \mathrm{~h}$ & 7.2 & 25.5 & 21.48 & 32.3 & 10.3 & 0.03 & 2.43 & 0.16 & 0.6 \\
\hline $1176^{\circ} \mathrm{C}, 3 \mathrm{~h}$ & 17.0 & 23.4 & 14.7 & 30.4 & 10.75 & 0.03 & 3.32 & 0.2 & 0.2 \\
\hline
\end{tabular}

\section{INCREASING OF THE MECHANICAL STRENGTH OF MPP SAMPLES}

An increase in the mechanical strength of magnesium-potassium phosphate samples was achieved by the addition of reinforcing additives of wollastonite $\mathrm{CaSiO}_{3}$ and slag from the metallurgical plants. It is well known that slags, sludges and other metallurgical waste are good sorbents for both heavy metals and radionuclides [19]. In addition, the inclusion of slag can increase the mechanical strength of the MPP materials, as well as increase the sorption capacity, which is very important for the immobilization of radioactive waste.

In the case of the wollastonite addition, it was established by XRD phase analysis that the composition of MPP + wollastonite composite material consists mainly of magnesium-potassium phosphate $\mathrm{KMgPO}_{4} \cdot 6 \mathrm{H}_{2} \mathrm{O}$, wollastonite $\mathrm{CaSiO}_{3}$ (JCPDS 45-0156), and magnesium oxide $\mathrm{MgO}$ (JCPDS 45-0946) (Fig. 5,a).

Fig. 5,b shows a SEM image of the microstructure (scanning electron microscope JSM-7001F (JEOL, Japan)) sample of the composition of MPP $+10 \mathrm{wt} . \%$ wollastonite. The microstructure of the sample is a magnesium-potassium-phosphate matrix with the additions of well-visible crystals of wollastonite. The crystals of wollastonite act as the second phase, which enhances the magnesium-potassium phosphate matrix. There is a tendency to increase the tensile strength of the MPP samples with the increasing in the amount of added wollastonite. Thus, the tensile strength without additives of wollastonite is about $8.6 \mathrm{MPa}$, with the addition of $10 \mathrm{wt} . \%$ wollastonite $-14.7 \mathrm{MPa}$, with the addition of $15 \mathrm{wt} . \%-17.5 \mathrm{MPa}$, and $20 \mathrm{wt} . \%$.23.2 MPa.

The composition of blast furnace slag, the properties and amount depend on the chemical and mineralogical composition of the iron ore rock, coke ash, sulfur content in the charge, the nature of the recovery process and the thermal state of the furnace, as well as the brand of smelted iron. The blast furnace slag is based on $\mathrm{CaO}$, $\mathrm{SiO}_{2}, \mathrm{~A}_{2} \mathrm{O}_{3}, \mathrm{MgO}$, and $\mathrm{FeO}$ oxides. For most slags, the mass fraction of the first four oxides is about $90 \%$ [20].
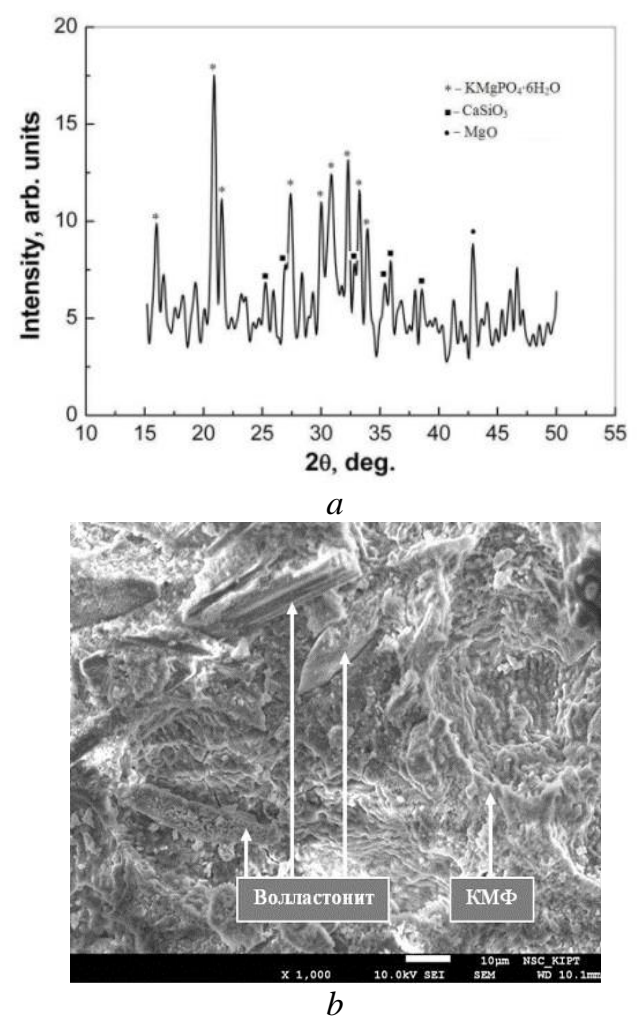

Fig. 5. The sample of $\mathrm{MPP}+10 \mathrm{wt} . \% \mathrm{CaSiO}_{3}$ composition: $a-X R D$ patterns, $b-S E M$ image

Using XRD phase analysis, it was established that the main phase of the MPP +15 wt.\% slag from the Mariupol Metallurgical Plant, the Zaporizhstal Steel Plant and the Dnieper Metallurgical Plant is $\mathrm{KMgPO}_{4} \cdot 6 \mathrm{H}_{2} \mathrm{O}$ magnesium-potassium phosphate, which provides a K-struvite structure. K-struvite structure is a base of matrix and saves integrity of the material (Fig. 6,a). In addition to the main phase, the 
oxermanite $\mathrm{Ca}_{2} \mathrm{MgSi}_{2} \mathrm{O}_{7}$, gelenite $\mathrm{Ca}_{2} \mathrm{Al}_{2} \mathrm{SiO}_{7}$, two calcium silicate $\mathrm{Ca}_{2} \mathrm{SiO}_{4}$ and residues $\mathrm{MgO}$, which did not react [21], were identified in the sample MPP + 15 wt.\% slag from the Mariupol Metallurgical Plant.

The compressive strength tests of magnesiumpotassium phosphate samples with the addition of 10 , 15 and $20 \mathrm{wt} . \%$ slag from metallurgical plants showed that sample of MPP +20 wt.\% slag from the Mariupol Metallurgical Plant has a maximum compressive strength $31.6 \mathrm{MPa}$ compared to samples of other compositions. The presence of a large number of magnesium-containing phases and stable triple oxides in the composition of the slag from the Mariupol Metallurgical Plant probably leads to the formation of a sufficient number of reinforcing particles in the MPP matrix, which provides the maximum value of strength.

\section{IMMOBILIZATION OF CS IMPREGNATED CLINOPTILOLITE INTO MPP MATRIX}

One of the main methods for the extraction of radionuclides from LRW generated by the operation of a NPP is the sorption method. Natural and synthetic zeolites, among others, are used as inorganic sorbents. Natural zeolites are much cheaper than synthetic zeolites and have a high ion-exchange capacity and mechanical strength. The reversibility of the ion exchange reaction leads to the creation of conditions for leaching of radionuclides during storage of spent sorbents [22]. Therefore, for reliable isolation of waste sorbents, it is necessary to ensure radionuclides inclusion in the matrix material and further guarantee of the localization of radionuclides during storage and subsequent disposal.

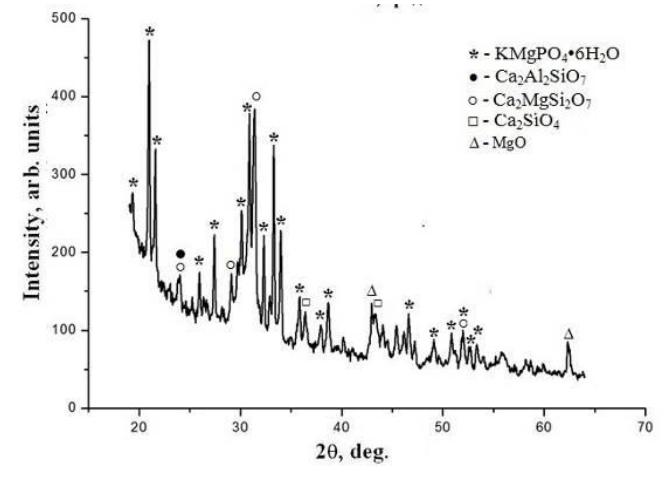

$a$

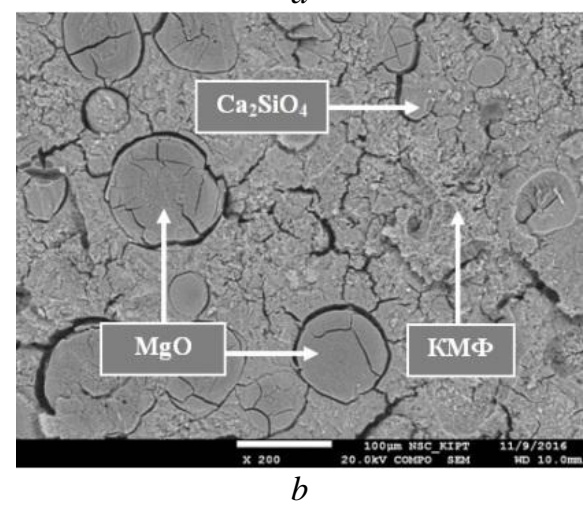

Fig. 6. The sample of MPP+15wt.\% slag from the Mariupol Metallurgical Plant composition: $a-X R D$ patterns; $b$-SEM image
A natural clinoptilolite from Sokirnytsky deposit of Transcarpathian region, impregnated with cesium was used as a simulator of the spent sorbent. XRD phase analysis of the natural clinoptilolite sample showed that it consists of two main phases: clinoptilolite $(\mathrm{Na}, \mathrm{K})_{4} \mathrm{CaAl}_{6} \mathrm{Si}_{30} \mathrm{O}_{72} \cdot 24 \mathrm{H}_{2} \mathrm{O}$ (JCPDS 24-0319) and mordenite $\left(\mathrm{Na}_{2} \mathrm{Ca}, \mathrm{K}_{2}\right)_{4} \mathrm{Al}_{8} \mathrm{Si}_{40} \mathrm{O}_{96} \cdot 28 \mathrm{H}_{2} \mathrm{O} \quad$ (RRUFF R070524). In addition, the impurities of $\mathrm{SiO}_{2}, \mathrm{Fe}_{2} \mathrm{O}_{3}$, and $\mathrm{TiO}_{2}$ phases were observed.

The solution of cesium chloride $0.5 \mathrm{M}$ was used to impregnate the clinoptilolite with cesium. Prior to the adding of cesium-clonoptilolite in MPP matrix, the matrix was ground in a planetary mill (Pulverisette 6, Germany) for $4 \mathrm{~h}$ at $300 \mathrm{rpm}$. XRD phase analysis of crushed clinoptilolite with cesium showed a tendency to decrease the amount of mordenite. The mordenite material undergoes more significant destruction during grinding process due to the fact that the strength of mordenite is lower compared to clinoptilolite (Fig. 7,a). To obtain the magnesium-potassium phosphate matrix of $25 \mathrm{wt} . \%$ impregnated with cesium, potassium dihydrophosphate solution was added to a stirred mixture of starting reagents $(\mathrm{MgO}$, clinoptilolite + $\mathrm{CsCl}$ ) according to a stoichiometric ratio. The obtained material is identified as the magnesium-potassium phosphate matrix with the presence of unreacted clinoptilolite, mordenite, $\mathrm{TiO}_{2}$, and $\mathrm{MgO}$ phases (see Fig. 7,b) [23].
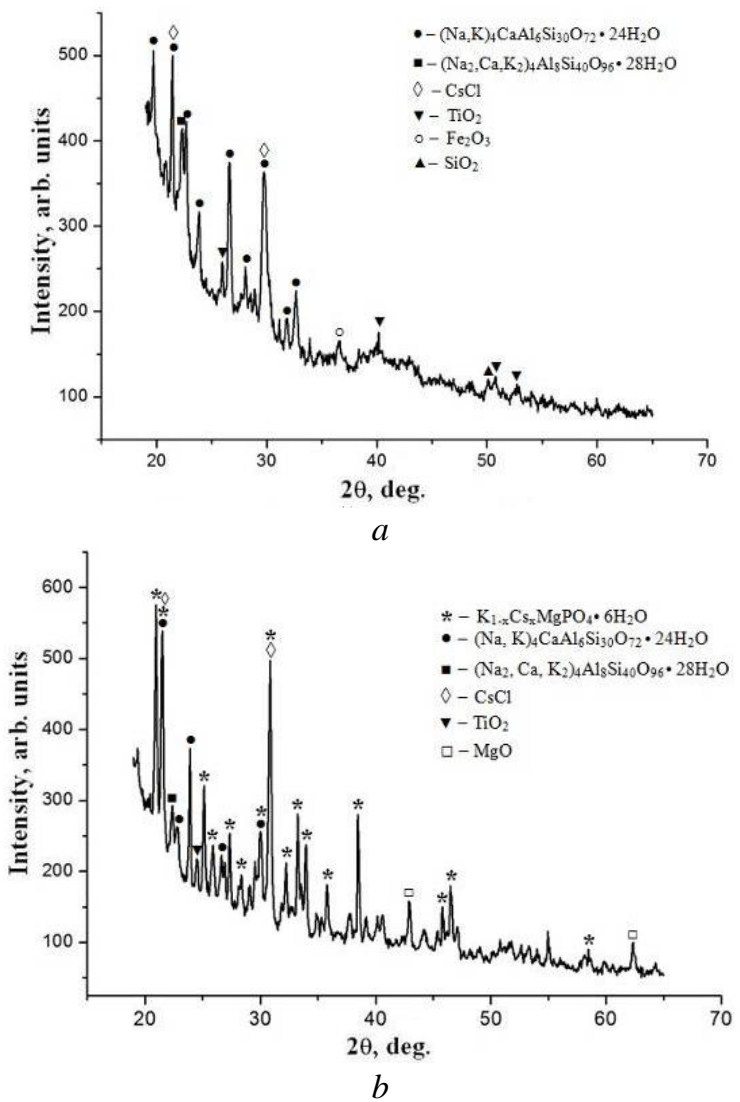

Fig. 7. XRD phase analysis of samples: $a-$ clinoptilolite $+\mathrm{CsCl}$ (grinding for $4 \mathrm{~h}$ at $300 \mathrm{rpm}$ ), $b-\mathrm{KMgPO}_{4} \cdot 6 \mathrm{H}_{2} \mathrm{O}+25$ wt. $\%$ clinoptilolite $+\mathrm{CsCl}$

The study of the microstructure of the samples of magnesium-potassium phosphate matrix $+25 \mathrm{wt} . \%$ clinoptilolite with cesium shows that the heterogeneity 
of the structure from fibrous formations to grains of irregular shape was observed in different parts of the sample (Fig. 8). The elemental analysis of the sample's composition by the energy dispersive X-ray microanalysis method (INCA Penta FETx3 analyzer, Oxford Instruments, United Kingdom) revealed that the fibrous structure is mainly represented by the magnesium-potassium-phosphate matrix with a small amount of clinoptilolite and cesium ( 3.5 wt.\%) elements. In turn, the grain structure consists of elements of both magnesium-potassium phosphate and clinoptilolite and contains a greater amount of cesium 13 wt.\% (Table 3). This means that probably some part of the cesium is incorporated into the magnesiumpotassium phosphate structure and the other part was remained into the clinoptilolite encapsulated into the phosphate matrix.

Table 3

Elemental composition of the grains structure of MPP +25 wt.\% clinoptilolite with cesium

\begin{tabular}{|c|c|c|c|c|c|c|c|c|}
\hline Element & $\mathrm{O}$ & $\mathrm{Mg}$ & $\mathrm{Al}$ & $\mathrm{Si}$ & $\mathrm{P}$ & $\mathrm{K}$ & $\mathrm{Cs}$ & Total \\
\hline Wt. $\%$ & 45.91 & 8.80 & 0.96 & 6.58 & 14.46 & 10.67 & 12.62 & 100.00 \\
\hline
\end{tabular}
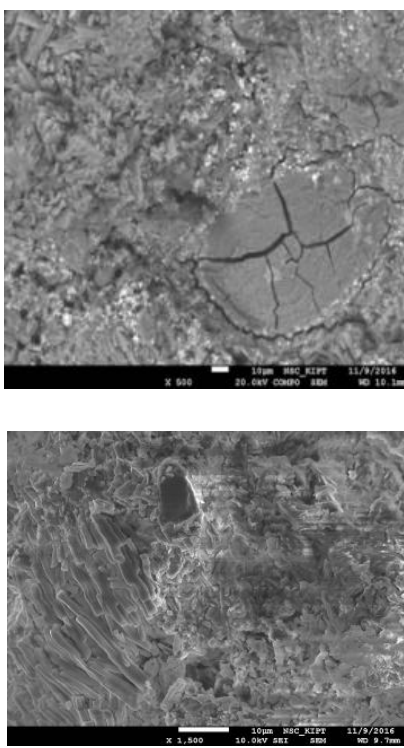
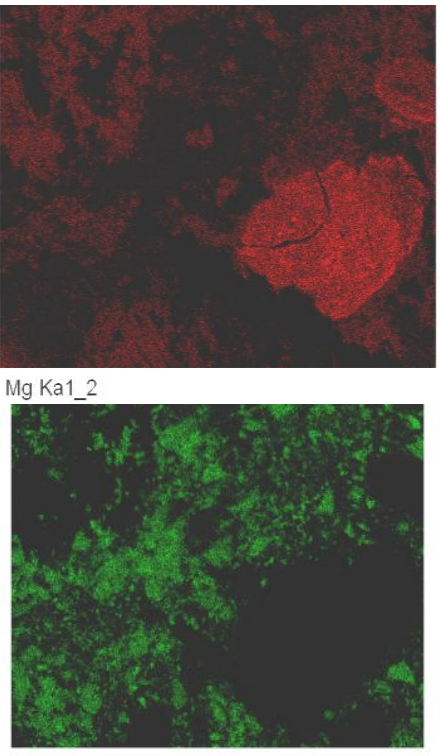

Si Ka1

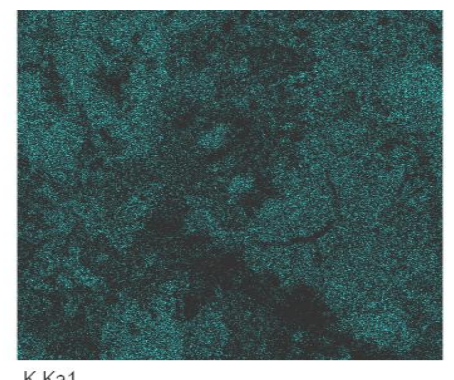

K. Ka1

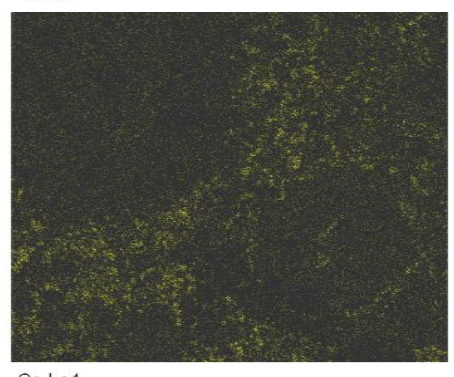

CSLa1

Fig. 8. SEM image of sample of MPP matrix $+25 w t . \%$ clinoptilolite with cesium and distribution maps of main elements

Fig. 8 presents the distribution maps of the main elements of the obtained material. Comparison of distribution maps of the cesium with the components of the MPP and the clinoptilolite further confirms the conclusion that most of the cesium is contained in the channels of the clinoptilolite encapsulated in the MPP matrix.

Corrosion tests were carried out by leaching of sample's materials of MPP matrix +25 wt. $\%$ clinoptilolite with cesium. Results demonstrate that normalized leaching rate of cesium after 7 days of testing was about $2.58 \cdot 10^{-4} \mathrm{~g} /\left(\mathrm{cm}^{2} \cdot\right.$ day $)$, and in order to magnitude less than leaching rate of cesium from cemented forms of waste.

\section{IMMOBILIZATION OF SIMULATORS OF LIQUID HIGH-SALT WASTE OF THE HANFORD (USA) DISPOSAL INTO THE MPP MATRICES}

Study on the immobilization of bottom sediment simulators of liquid high saline wastes from HWF reservoirs at Hanford (USA) in MPP matrices was carried out in ISSPMT NSC KIPT in cooperation with the Argon National Laboratory (ANL, USA) in the framework of STCU P-547 partnership project. The radioactive waste has been generated during plutonium production more than 45 years and contains a large number of long-lived fission products and transuranium elements. The bottom sediments contain $95 \%$ of the total ${ }^{90} \mathrm{Sr}$ and more than $90 \%$ of the transuranium elements stored in the tank. The bottom sediments contain quite high concentrations of elements such as $\mathrm{Fe}, \mathrm{Al}, \mathrm{Ca}, \mathrm{Na}, \mathrm{U}, \mathrm{Cr}, \mathrm{Pb}$, and others, and demonstrate high activity due to the presence of the following radionuclides: ${ }^{239} \mathrm{Pu},{ }^{240} \mathrm{Pu},{ }^{241} \mathrm{Pu},{ }^{137} \mathrm{Cs},{ }^{90} \mathrm{Sr},{ }^{237} \mathrm{~Np}$, ${ }^{241}$ Am [24]

Compositions of high salt wastes of K-Basin bottom sediments (K-East or $\mathrm{KE}$ and $\mathrm{K}$-West or $\mathrm{KW}$ ) were investigated. Non-radioactive radioactive waste simulators were obtained by mixing radioactive isotope simulators with other non-radioactive components in water. The main components and simulators of actinides were added in the form of oxides or carbonates. The Am elements were simulated by $\mathrm{Sm}, \mathrm{Np}$ using $\mathrm{Pr}, \mathrm{Pu}-\mathrm{Ce}$, and $\mathrm{U}-\mathrm{Nd}$. Non-radioactive $\mathrm{Cs}$ and $\mathrm{Sr}$, representing by isotopes (fission products), were also added as carbonates. Dangerous elements were added as chlorides, except for $\mathrm{Cr}$, which was added as $\mathrm{Cr}_{2} \mathrm{O}_{3}$. After KE and KW Basin (Floor sludge) waste simulators were prepared, elemental analysis was made using EMAL-2 laser mass spectrometer to ensure that solids content was consistent with the data presented in the review [24]. The results of the analysis together with the required KE and KW Basin waste simulator's 
compositions are presented in Table 4. Overall consistency between the required and the prepared composition was achieved. The slight deviations between the required and the measured quantities are probably related to the potential limitation of the mathematical model used to calculate the corresponding quantities of simulators.

Solidification of the waste simulators $\mathrm{KW} / \mathrm{KE}$ Basin sludge was performed by adding first $\mathrm{KH}_{2} \mathrm{PO}_{4}$ with continuous stirring and then $\mathrm{MgO}$ in the ratio $\mathrm{MgO}(\mathrm{g})$ : $\mathrm{KW} / \mathrm{KE}$ Basin sludge (ml): $\mathrm{KH}_{2} \mathrm{PO}_{4}(\mathrm{~g})=1: 2: 3$ (Fig. 9).

The results of the XRD phase analysis of the obtained matrices showed that the crystalline phase in the samples of $\mathrm{KW} / \mathrm{KE}$ Basin sludge waste simulators corresponds essentially to the magnesium potassium phosphate $\mathrm{KMgPO}_{4} \cdot 6 \mathrm{H}_{2} \mathrm{O}$. In this case, a small number of lines of other phases and a slight shift of the basic lines of magnesium-potassium phosphate on the diffraction patterns of the $\mathrm{KW} / \mathrm{KE}$ Basin sludge waste simulators were observed. This fact may be related to the formation of the variable $\mathrm{KMgPO}_{4} \cdot 6 \mathrm{H}_{2} \mathrm{O}$ phase composition due to partial replacement of potassium by sodium and magnesium by iron.

The effect of the content of KW/KE Basin sludge waste simulators on the strength characteristics of the solidified product was investigated. It was shown, that the increase of the amount of added waste simulators in MPP matrix from 33.3 to $39.4 \mathrm{wt}$ \% leads to a tendency of the compressive strength increasing of the samples of the solidified simulators $\mathrm{KW} / \mathrm{KE}$ Basin sludge waste. The compressive strength of the obtained samples was more than $9 \mathrm{MPa}$, which complies with the requirements of GOST R 50926-96 [25].
In order to investigate the radiation resistance, the magnesium-potassium phosphates and the solidified simulators of the $\mathrm{KW} / \mathrm{KE}$ Basin sludge waste were irradiated by electron irradiation to dose of $10^{10} \mathrm{rad}$ $\left(10^{8} \mathrm{~Gy}\right)$ and by bremsstrahlung $\gamma$-excitation to dose of $10^{8} \mathrm{rad}\left(10^{6} \mathrm{~Gy}\right)$ using the KUT-1 electron accelerator (electron energy up to $10 \mathrm{MeV}$ ).
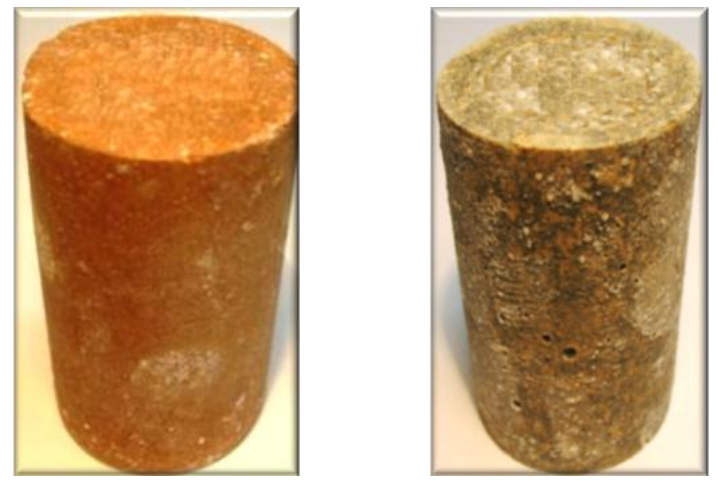

Fig. 9. Solidified simulators of the $K W$ and KE Basin sludge waste

The density, the compressive strength and the phase composition of the samples before and after irradiation were also determined. It was found that the density and compressive strength of the solidified simulators $\mathrm{KW} / \mathrm{KE}$ Basin sludge waste did not significantly change. In appearance, the irradiated $\gamma$-radiation and electron samples did not differ from the non-irradiated samples. No changes in the volume and apparent damage of the samples were observed.

Required and obtained KE and KW Basin waste simulator's compositions

\begin{tabular}{|c|c|c|c|c|}
\hline \multirow{2}{*}{ Element } & \multicolumn{4}{|c|}{ K-Basin sludge, g/l } \\
\cline { 2 - 5 } & \multicolumn{2}{|c|}{ KE } & KW \\
\cline { 2 - 5 } & $\begin{array}{c}\text { Required } \\
\text { composition }\end{array}$ & $\begin{array}{c}\text { Obtained } \\
\text { composition }\end{array}$ & $\begin{array}{c}\text { Required } \\
\text { composition }\end{array}$ & $\begin{array}{c}\text { Obtained } \\
\text { composition }\end{array}$ \\
\hline 1 & 2 & 3 & 4 & 5 \\
\hline $\mathrm{B}$ & 0.127 & 0.177 & - & 0.0022 \\
$\mathrm{C}$ & - & 0.148 & - & 0.372 \\
$\mathrm{~N}$ & - & 16.598 & - & 27.54 \\
$\mathrm{O}$ & - & 353.5 & - & 248.5 \\
$\mathrm{Na}$ & 2.055 & 8.78 & - & 3.66 \\
$\mathrm{Mg}$ & 1.098 & 4.65 & - & 0.216 \\
$\mathrm{Al}$ & 45.05 & 90.0 & 45.05 & 62.16 \\
$\mathrm{Si}$ & - & 0.66 & - & 0.252 \\
$\mathrm{P}$ & - & 0.0295 & - & 0.00588 \\
$\mathrm{~S}$ & - & 69.344 & - & 96.78 \\
$\mathrm{Cl}$ & - & 0.0347 & - & 0.228 \\
$\mathrm{~K}$ & 1.52 & 2.065 & - & 0.222 \\
$\mathrm{Ca}$ & 3.607 & 2.51 & 3.607 & 6.9 \\
$\mathrm{Cr}$ & 0.352 & 2.066 & 0.352 & 2.82 \\
$\mathrm{Mn}$ & 0.3315 & 0.738 & - & 0.186 \\
$\mathrm{Fe}$ & 144.1 & 147.466 & 144.1 & 126.72 \\
$\mathrm{Ni}$ & 0.056 & 0.032 & - & 0.0144 \\
$\mathrm{Co}$ & - & 0.0036 & - & - \\
$\mathrm{Cu}$ & 0.3584 & 0.332 & 0.0216 & 0.078 \\
$\mathrm{Sr}$ & 0.0025 & 0.148 & 0.0013 & - \\
$\mathrm{Zr}$ & 0.214 & 0.063 & 0.0013 & - \\
$\mathrm{Ba}$ & 0.148 & 0.14 & 0.148 & - \\
\hline & & & & \\
\hline
\end{tabular}




\begin{tabular}{|c|c|c|c|c|}
\hline 1 & 2 & 3 & 4 & 5 \\
\hline $\mathrm{Ce}$ & 0.0396 & 4.13 & 0.0216 & 0.078 \\
$\mathrm{Cd}$ & 0.083 & - & - & - \\
$\mathrm{Zn}$ & 0.559 & 0.68 & - & - \\
$\mathrm{Pb}$ & - & - & 0.259 & 0.0588 \\
$\mathrm{Cs}$ & 0.005 & - & 0.0029 & 0.408 \\
$\mathrm{Pr}$ & 0.009 & - & - & - \\
$\mathrm{Zr}$ & 0.214 & 0.063 & - & - \\
$\mathrm{Nd}$ & 53.83 & 27.22 & 53.83 & 15.6 \\
\hline
\end{tabular}

After the MPP samples irradiation by bremsstrahlung $\gamma$-irradiation to the set of absorbed doses up to dose of $10^{8} \mathrm{rad}$, no phase changes were observed. Figs. 5,a and 10,a show the diffraction patterns of the sample composition $\left(\mathrm{KMgPO}_{4} \cdot 6 \mathrm{H}_{2} \mathrm{O}+10 \mathrm{wt} . \%\right.$ $\mathrm{CaSiO}_{3}$ ) before and after $\gamma$-irradiation. The diffraction patterns comparison shows the complete coincidence of the main X-ray lines of magnesium-potassium phosphate before and after $\gamma$-irradiation. In contrast to $\gamma$-irradiation, after electron irradiation to the set of absorbed dose up to dose of $10^{10} \mathrm{rad}$ the diffraction patterns of the sample composition $\left(\mathrm{KMgPO}_{4} \cdot 6 \mathrm{H}_{2} \mathrm{O}+\right.$ 10 wt. $\% \mathrm{CaSiO}_{3}$ ) demonstrate $\mathrm{X}$-ray lines of the magnesium-potassium phosphate monohydrate $\mathrm{KMgPO}_{4} \cdot \mathrm{H}_{2} \mathrm{O}$, magnesium-potassium phosphate $\mathrm{KMgPO}_{4}$, wollastonite $\mathrm{CaSiO}_{3}$ and magnesium oxide $\mathrm{MgO}$ on the halo background at angles in the range $20^{\circ}$ $2 \theta-40^{\circ}$ (see Fig. 10,b). This fact indicates that after irradiation by high-energy electrons $(10 \mathrm{MeV})$ dehydration and amorphization of MPP samples took place [26].

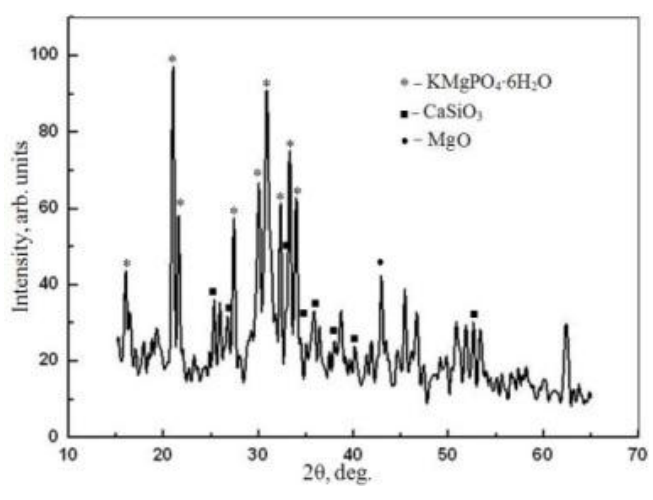

$a$

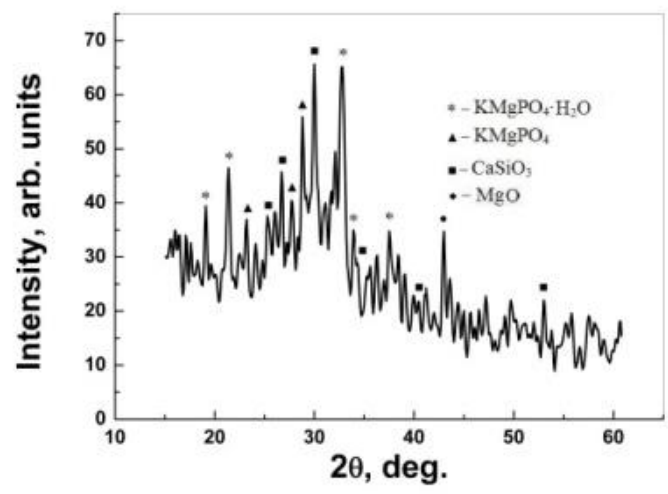

b

Fig. 10. Diffraction patterns of the sample composition $\left(\mathrm{KMgPO}_{4} \cdot 6 \mathrm{H}_{2} \mathrm{O}+10 \mathrm{wt} \% \mathrm{CaSiO}_{3}\right)$ :

$a$-after $\gamma$-irradiation process; $b$ - after electron irradiation process
The corrosion properties of MPP matrices were determined by leaching in water samples of the compositions $\left(\mathrm{KMgPO}_{4} \cdot 6 \mathrm{H}_{2} \mathrm{O}+(10 \ldots 15)\right.$ wt. $\left.\% \mathrm{CsCl}\right)$ and solidified simulators $\mathrm{KW} / \mathrm{KE}$ Basin sludge waste, in accordance with the requirements of PCT and ANS 16.1 tests $[27,28]$. The concentration of elements in solution after leaching was determined by atomic emission spectroscopy with inductively coupled plasma ICP-AES (Trace Scan Advantage spectrometer manufactured by Thermo Jarrell Ash, USA). The leaching rate values were calculated from the PCT test and shown that the basic elements of the MPP matrix, such as potassium, magnesium, and phosphorus have very low leaching rates of about $10^{-6} \ldots 10^{-3} \mathrm{~g} /\left(\mathrm{m}^{2} \cdot\right.$ day $)$ [29].

Low values of leaching rates $\left(10^{-4} \ldots 10^{-7} \mathrm{~g} /\left(\mathrm{cm}^{2} \cdot\right.\right.$ day $\left.)\right)$ of $\mathrm{Cs}, \mathrm{Sr}, \mathrm{Eu}, \mathrm{Nd}, \mathrm{Sm}, \mathrm{Ce}$, and $\mathrm{Pr}$ after 90 days of leaching at $25^{\circ} \mathrm{C}$ according to ANS 16.1 test, demonstrated high corrosion resistance of the obtained protective matrices on the basis of magnesium-potassium phosphate against leaching of radionuclides simulators.

\section{CONCLUSIONS}

1. The method of Cs encapsulating into the protective matrix based on magnesium-potassium phosphate $\mathrm{KMgPO}_{4} \cdot 6 \mathrm{H}_{2} \mathrm{O}$ was developed by means of synthesis at room temperature. X-ray phase analysis of the synthesized materials after cesium incorporating showed that the crystalline structure of $\mathrm{K}_{1-\mathrm{x}} \mathrm{C}_{\mathrm{sx}} \mathrm{MgPO}_{4}$. $6 \mathrm{H}_{2} \mathrm{O}$ was not changed in comparison with $\mathrm{KMgPO}_{4} \cdot 6 \mathrm{H}_{2} \mathrm{O}$ material. There was a slight increase in the parameters of the crystalline lattice of magnesiumpotassium phosphate with cesium, which confirms the isomorphic substitution of part of $\mathrm{K}$ atoms by $\mathrm{Cs}$ atoms. The Cs incorporated in the MPP matrix has demonstrated low leaching rates in water and did not enter the environment even heated to high temperatures.

2. The increasing of mechanical strength of magnesium-potassium phosphate samples by the adding of reinforced additives of $\mathrm{CaSiO}_{3}$ wollastonite and slag of the metallurgical plants was detected. The maximum value of the compressive strength was obtained on samples of the composition MPP + $20 \mathrm{wt} \%$ slag from the Mariupol Metallurgical Plant.

3. The study was carried out to incorporate cesiumimpregnated clinoptilolite into the magnesiumpotassium phosphate matrix. The analysis of the microstructure and elemental composition of the samples (MPP matrix +25 wt. \% clinoptilolite with cesium) showed that part of the cesium incorporated to the structure of magnesium-potassium phosphate and the other part was remained in the clinoptilolite encapsulated in the MPP matrix. Corrosion tests were performed by leaching of sample materials (MPP matrix 
+25 wt. \% clinoptilolite with cesium). Results have shown that the normalized rate of leaching of cesium after 7 days of testing was $2.58 \cdot 10^{-4} \mathrm{~g} /\left(\mathrm{cm}^{2} \cdot\right.$ day $)$.

4. The studies on the immobilization of simulators of liquid high-salt radioactive waste from reservoirs at Hanford were carried out. The results of the XRD phase analysis of the obtained matrices showed that the X-ray lines mainly correspond to crystalline magnesiumpotassium phosphate $\mathrm{KMgPO}_{4} \cdot 6 \mathrm{H}_{2} \mathrm{O}$. Electron irradiation and $\gamma$-irradiation did not lead to significant changes in the appearance and size of the samples of the solidified Hanford waste simulators, In addition, no significant effect on the density and tensile strength of the samples was detected. The obtained MPP protective matrices demonstrated high corrosion resistance with respect to leaching rates of stable $\mathrm{Cs}, \mathrm{Sr}, \mathrm{Ce}, \mathrm{Pr}, \mathrm{Sm}$, $\mathrm{Co}, \mathrm{Nd}$ elements imitating radionuclides $\left(10^{-4} \ldots 10^{-6} \mathrm{~g} /\left(\mathrm{cm}^{2} \cdot\right.\right.$ day $\left.)\right)$.

5. Comprehensive research was conducted to substantiate the application of magnesium-potassium phosphate materials for the immobilization of radioactive waste. The obtained results of the MPP matrices using for immobilization of cesium, clinoptilolite with cesium, and the simulators of Hanford high-salt waste give good grounds for considering the application of MPP matrices for solidification of LRW of Ukrainian NPPs.

\section{REFERENCES}

1. В.М. Ажажа, В.А. Белоус, С.Ю. Саенко и др. Ядерная энергетика. Обращение с отработанным ядерным топливом и радиоактивными отходами / Под ред. акад. НАНУ И.М. Неклюдова. Киев: «Наукова думка», 2006, 253 с.

2. В.Р. Ахмедзянов, Т.Н. Лащёнова, О.А. Максимова. Обращение с радиоактивными отходами М.: «Энергия, Институт энергетической стратегии», 2008, 284 с.

3. И.А. Соболев, Л.М. Хомчик. Обезвреживание радиоактивных отходов на иентрализованных nунктах. М.: «Энергоатомиздат», 1983, 128 с.

4. W.D. Kingery. Fundamental Study of Phosphate Bonding in Refractories: II, Cold-Setting Properties // J. Am. Ceram. Soc. 1950, N 33(5), p. 242-250.

5. S.Y. Jeong and A.S. Wagh. Chemically bonded phosphate ceramics: cementing the gap between ceramics and cements // U.S. Department of Energy. Office of Science and Technology. Contract W-31109-Eng-38. 2002, p. 18.

6. A.S. Wagh, D. Singh, S.Y. Jeong, and R.V. Strain. Ceramicrete stabilization of low-level mixed wastes - a complete story // Energy Technology. Division Argonne National Laboratory Argonne, IL 60439. 1997, p. 8.

7. D. Singh, V.R. Mandalika, S.J. Parulekar, A.S. Wagh. Magnesium potassium phosphate ceramic for ${ }^{99} \mathrm{Tc}$ immobilization // Journal of Nuclear Materials. 2006, N 348, p. 272-282.

8. A.S. Wagh. Chemical bonded phosphate ceramics. Elsevier, Argonne National Laboratory, ISBN: 0-08-044505-5, USA, 2004, 283 p.

9. Ю.О. Ольховик, П.О. Корчагін. Щодо вибору в'яжучих матеріалів для цементування кубового залишку АЕC 3 реакторами ВВЕР // Ядерна енергетика та довкілля. 2014, №1(3), с. 20-23.

10. S. Arun Wagh, Dileep Singh, and SeungYoung Jeong. Chemically bonded phosphate ceramics for stabilization and solidification of mixed waste // Hazardous and Radioactive Waste Treatment Technologies: Handbook, CRC Press, Boca Raton, FL, 2001, p. 6.3.1-6.3.18.

11. С.А. Кулюхин, Н.А. Коновалова, М.П. Горбачева и др. Извлечение ${ }^{60} \mathrm{Co}$ и ${ }^{137} \mathrm{Cs}$ из модельного раствора трапных вод АЭС // Радиохимия. 2013, т. 55, №3, с. 242-248.

12. Arun S. Wagh, S.Y. Sayenko, V.A. Shkuropatenko, et al. Experimental study on cesium immobilization in struvite structures // Journal of Hazardous Materials. 2016, N 302, p. 241-249.

13. S.Y. Sayenko, Arun S. Wagh, V.A. Shkuropatenko, et al. Cesium immobilization into potassium magnesium phosphate matrix // Problems of Atomic Science and Technology. Series "Physics of Radiation Effects and Radiation Materials Science". 2017, N 4(110), p. 65-73.

14. Siyu Zhang, Hui-Sheng, Shao-Wen Huang, Ping Zhang. Dehydration characteristics of struvite-K pertaining to magnesium potassium phosphate cement system in non-isothermal condition // J. Therm Anal Calorim. 2013, N 111, p. 35-40.

15. G. Wallez, C. Colbeau-Justin, T. Le Mercier, M. Quarton, and F. Robert. Crystal Chemistry and Polymorphism of Potassium-Magnesium Monophospate // Journal of Solid State Chemistry. 1998, v. 136, p. 175-180.

16. Suyin Zhang, Yanlin Huang, Hyo Jin Seo. Luminescence properties and structure of $\mathrm{Eu}^{2+}$ doped $\mathrm{KMgPO}_{4}$ phosphor // Optical Materials. 2010, v. 32, p. $1545-1548$.

17. Frost Ray L., Xi Yunfei, Palmer Sara J., Keqin Tan and Ross, Millar Graeme J. Vibrational spectroscopy of synthetic archerite $\left(\mathrm{K}, \mathrm{NH}_{4}\right) \mathrm{H}_{2} \mathrm{PO}_{4}$ : and in comparison with the natural cave mineral // Journal of Molecular Structure. 2012, v. 1011, p. 128-133.

18. А.С. Поваренных. Связь ИК-спектров минералов с кристаллохимическими факторами // Минерал. сборник Львовского государств. университета. 1970, в. 1, №24, с. 12-29.

19. Н.М. Барышева, Е.В. Поляков, Г.П. Швейкин и др. Новые неорганические сорбенты радионуклидов и тяжелых металлов. Разработка технологии синтеза из металлургических отходов // Сотрудничество для решения проблемь отходов: Мат. 6-й Междунар. конф. Харьков, 2009, с. 57-60.

20. Э.Б. Хоботова, М.И. Уханева, И.В. Грайворонская, Ю.С. Калмыкова. Радиационно-химическое обоснование использования твердых промышленных отходов в качестве технических материалов. Харьков: ХНАДУ, 2012, 260 с.

21. С.Ю. Саенко, В.А. Шкуропатенко, Р.В. Тарасов и др. Упрочнение калий-магний-фосфатного цемента путем введения добавок волластонита и шлаков металлургических комбинатов // Збірник наукових праць ПАТ «УКРНДІ вогнетривів ім. А.С. Бережного». 2017, №117, с. 125-137. 
22. А.С. Никифоров,

В.В. Кулиниченко, М.И. Жихарев. Обезвреживание жидких радиоакmивнылх отходов. М: «Энергоатомиздат», 1985 , $183 \mathrm{c}$.

23. S.Yu. Sayenko, V.A. Shkuropatenko, N.P. Dikiy, et al. Clinoptilolite with cesium immobilization into potassium magnesium matrix // East Eur. J. Phys. 2017, v. 4, N 2, p. 37-43.

24. Hanford K-Basin characterization overview, US EPA (2005). http://www.epa.gov/rpdweb00/docs/ wipp/doeenclosure9_1.pdf.

25. ГОСТ Р 50926-96. Отходы высокоактивные отвержденные. Общие технические требования. М.: «Госстандарт России», 1996, с. 6.

26. Jovanovski Gligor, Pocev Stefan, Kaitner Branko. Crystal structure of magnesium potassium phosphate monohydrate $\left(\mathrm{MgKPO}_{4} \mathrm{H}_{2} \mathrm{O}\right)$ // Glasnikna hemicharitei tehnolozitena Makedonija. 1997, N 16(1), p. 59-63.
27. Standard Test Methods for Determining Chemical Durability of Nuclear, Hazardous, and Mixed Waste Glasses and Multiphase Glass Ceramics: The Product Consistency Test (PCT). Published August 2008. Originally approved in 1994. Last previous edition approved in 2002 as $\mathrm{C} 1285$ - 02; DOI: 10.1520/C1285-02R08.

28. Measurement of the Leachability of Solidified Low-Level Radioactive Wastes by a Short-Term Test Procedure: ANSI/ANS 16.1 - 1986. La Grange Park, IL: Am. Nat. Soc., 1986.

29. S.Y. Sayenko, V.A. Shkuropatenko, A.V. Zykova, et al. Corrosion and radiation resistance of potassium magnesium phosphate matrices // Problems of Atomic Science and Technology. Series "Physics of Radiation Effects and Radiation Materials Science". 2018, N 5(117), p. 75-81.

\title{
ЭКСПЕРИМЕНТАЛЬНОЕ ИССЛЕДОВАНИЕ ИММОБИЛИЗАЦИИ РАДИОАКТИВНЫХ ОТХОДОВ В НИЗКОТЕМПЕРАТУРНОЙ КАЛИЙ-МАГНИЙ-ФОСФАТНОЙ КЕРАМИЧЕСКОЙ МАТРИЦЕ
}

\author{
С.Ю. Саенко, В.А. Шкуропатенко, А.В. Пилипенко, А.В. Зыкова, С.А. Карсим, \\ B.В. Андреева, С.В. Мошта
}

Представлены результаты выполненных ННЦ ХФТИ работ по применению калий-магний-фосфатных керамических матриц для иммобилизации цезия, клиноптилолита с цезием и отверждения имитаторов высокосолевых высокоактивных отходов. Установлена высокая радиационная и коррозионная стойкости полученных матриц к выщелачиванию имитаторов радионуклидов и основных компонентов твердых керамических компаундов. Показано, что калий-магний-фосфатная матрица может быть использована для отверждения жидких радиоактивных отходов АЭС Украины низкого и среднего уровней активности, в том числе с увеличенным солесодержанием.

\section{ЕКСПЕРИМЕНТАЛЬНЕ ДОСЛІДЖЕННЯ ІММОБІЛІЗАЦІЇ РАДІОАКТИВНИХ ВІДХОДІВ У НИЗЬКОТЕМПЕРАТУРНІЙ КАЛІЙ-МАГНІЙ-ФОСФАТНІЙ КЕРАМІЧНІЙ МАТРИЦІ}

С.Ю. Саєнко, В.А. Шкуропатенко, О.В. Пилипенко, А.В. Зикова, С.О. Карсім, В.В. Андреєва, С.В. Моита

Представлені результати виконаних у ННЦ ХФТІ робіт по застосуванню калій-магній-фосфатних керамічних матриць для іммобілізації цезію, кліноптилоліту 3 цезієм та отвердження імітаторів високосольових високоактивних відходів. Встановлена висока радіаційна та корозійна стійкісті отриманих матриць до вилуговування імітаторів радіонуклідів та основних компонентів твердих керамічних компаундів. Показано, що калій-магній-фосфатна матриця може бути використана для отвердження рідких радіоактивних відходів АЕС України низького та середнього рівнів активності, у тому числі зі збільшеним солевмістом. 